\title{
PEMBUATAN KAMUS BAHASA USING BERGAMBAR SEBAGAI MEDIA BAGI SISWA SEKOLAH DASAR DI BANYUWANGI
}

\author{
Lutfi Irawan R1. Nur Hasibin2 \\ Universitas PGRI Banyuwangi \\ Jl. Ikan Tongkol No 01 Kertosari Banyuwangi \\ E-Mail: LUTFIIRAWAN04@GMAIL.COM
}

\begin{abstract}
Abstrak
Hasil penelitian ini berupa pembuatan buku berbahasa Using bergambar. Pada bagian pembukaan kamus terdapat halaman judul dalam, identitas buku, halaman judul singkat, persembahan, kata pengantar, petunjuk penggunaan kamus, dan daftar isi. Bagian isi berisi daftar kosakata yang dikemas berdasarkan tema dan disusun sesuai letak gambar. Adapun tema yang tersaji untuk isi kamus adalah tema anggota tubuh; tema warna; tema angka; dan tema silsilah kekeluargaan.Selain memaparkan kosakata yang diikuti gambar, dipaparkan juga halaman keterangan kosakata sulit. Bagian penutup terdapat daftar pustaka, dan biodata penulis.Berdasarkan hasil penelitian dan simpulan dalam penelitiaan ini, peneliti menyampaikan beberapa saran sebagai berikut. Pertama,buku berbahasa Using bergambar dapat digunakan sebagai salah satu sumber pustaka dalam proses belajar mengajar. Kedua, perlu diadakan penelitian lebih lanjut untuk menguji keefektifan buku berbahasa Using bergambar.
\end{abstract}

Kata Kunci: Buku, Using, Bergambar, Sekolah Dasar

\section{Latar Belakang}

Proses belajar mengajar di kelas membutuhkan perangkat pembelajaran yang beraneka ragam. Kegiatan belajar mengajar tidak hanya kegiatan bertatap muka, melainkan sebuah kegiatan yang terpadu dari persiapan, pelaksanaan, hingga evaluasi. Untuk melengkapi ketiga proses tersebut, guru hendaknya menyiapkan Silabus, Rencana Pelaksanaan Pembelajaran (RPP), Bahan Ajar Siswa, Lembar Kerja Siswa, Tes Hasil Belajar, Program Semester,Program Tahunan, hingga persiapan remedial bagi siswa yang tidak bisa mencapai Kriteria Ketuntasan Minimal (KKM). Perangkat pembelajaran tersebut merupakan sesuatu 
yang sifatnya saling melengkapi yang didasarkan pada kurikulum tertentu.

Perangkat pembelajaran menjadi sesuatu yang sangat penting sehingga ketentuan semacam ini menjadi salah satu bahasan Menteri Pendidikan dan Kebudayaan (Mendikbud RI). Salah satu contohnya sebagaimana yang tercantum dalam Permendikbud No. 8 Tahun 2016 yang menerangkan mengenai buku sebagai salah satu perangkat pembelajaran, didalam peraturan tersebut dijelaskan jenis buku, kriteria penilaian buku, sumber buku, hingga pengawasan buku dalam peredarannya.

Berdarsarkan Permendikbud No. 8

Tahun 2016 pasal 5 ayat (1) yang berbunyi: "Penerbitan buku teks pelajaran dapat dilakukan oleh Kementerian, Pemerintah Daerah, dan atau Swasta", dan berdasarkan Permendikbud No.8 Tahun 2016 pasal 6 ayat (3) yang berbunyi: "Kriteria atas kelayakan buku teks pelajaran yang diterbitkan oleh Pemerintah Daerah, atau Swasta dapat dilakukan penilaian oleh BSNP atau tim penilai yang ditetapkan oleh Menteri Pendidikan dan Kebudayaan”,

Memberikan isyarat bahwa penerbitan buku (dalam hal ini buku pelajaran) bisa dilakukan oleh Pemerintah Daerah atau Swasta dengan pengawasan langsung dari BSNP selaku penilai atau tim dari Bapak Menteri Pendidikan dan Kebudayaan. Oleh karena itu, sudah menjadi sebuah keharusan buku yang beredar di masyarakat mampu memenuhi kebutuhan pelajar baik dari segi kuantitas dan kualitas.

Menurut Prastowo (2012:6) yang memaparkan sebuah realita di dunia pendidikan yang berkaitan dengan kondisi guru dan dosen. Para guru dan dosen seringkali menggunakan bahan ajar buatan pabrik yang diperjualbelikan bebas. Padahal, mereka tahu bahwa bahan ajar yang mereka gunakan tidak sesuai dengan konteks dan kondisi sosial budaya peserta didik.

Realitas lain dikemukakan dalam seminar "Faculty Development Seminar" yang diadakan oleh Pusat Teknologi Komunikasi Pendidikan Kebudayaan (dalam Sadiman, 2011:v-vi) menyatakan bahwa adanya kelangkaan bahan-bahan pustaka pendidikan yang diperlukan untuk memungkinkan penyelenggaraan dan pengembangan pendidikan.

Dua fakta di atas menunjukkan bahwa peredaran buku pelajaran saat ini mengalami kendala baik dari segi kuantitas maupun kualitas. Dari segi kuantitas yaitu jumlah buku yang beredar kurang mencukupi untuk semua mata pelajaran maupun tematik dengan jumlah peserta didik. Kendala lain yaitu dari segi kualitas buku yang kurang sesuai dengan kurikulum dan kondisi sosial budaya masyarakat pengguna buku tersebut.

Peneliti berasumsi bahwa buku teks sangat penting bagi pembelajaran tetapi jangan

sampai guru menjadikan buku teks sebagai acuan. Peneliti berpendapat bahwa saat ini buku teks pelajaran lebih menekankan pada kemampuan kecerdasan intelektual siswa dan kurang membahas mengenai kecerdasan emosional atau kecerdasan sosial. Buku teks pelajaran ini cenderung membosankan. Oleh karena itu, perlu pengadaan buku yang berkualitas termasuk buku-buku, sumber/ buku referensi/ buku pengayaan yang bisa digunakan oleh guru untuk melakukan 
berbagai pengembangan dan inovasi pembelajaran.

Berdasarkan survei peneliti di beberapa penerbit buku pelajaran baik cetak maupun online di Kabupaten Banyuwangi, peneliti menemukan adanya kelangkaan buku referensin untuk bahasa Using. Penulis mengambil salah satu contoh buku bahasa Using, yaitu buku pegangan guru berupa kamus bahasa daerah Using-Indonesia karangan Hasan Ali cetak tahun 2001. Kemudian dari situs online, buku referensi sama sekali tidak ada, disini menunjukkan bahwa ketersediaan referensi untuk bahasa Using sangat minim sekali.

Disisi yang lain, buku referensi bahasa Using untuk penunjang pembelajaran bahasa Using mulai dibutuhkan. Menurut sejarahnya, bahasa Using sudah diajarkan sejak 1997, saat pertama diperkenalkan di tiga kecamatan, berdasar SK Kakanwil Depdikbud Provinsi Jatim tanggal 30 Januari 1996 No. 1751/104/D/1996. Lantas, diperkuat lagi dengan Peraturan

Daerah Kabupaten Banyuwangi No. 5 tahun 2007, yang pasal 3 berbunyi: "Pembelajaran bahasa Using sebagai kurikulum muatan lokal wajib dilaksanakan pada seluruh jenjang pendidikan dasar, baik negeri maupun swasta di Kabupaten Banyuwangi." Di jenjang Sekolah Dasar pembelajaran bahasa Using sendiri dimulai pada kelas tinggi yaitu kelas IV, V, dan VI. Salah satu contoh pada kelas IV SD Semester 1 dengan KD : "Ciri Uni Basa Using", ada satu tantangan bagi guru untuk membimbing siswa agar bisa menyebutkan dengan bahasa Using terkait dengan ciri uni basa Using ke beberapa hal, (a) diftongosasi, (b) umlautiasi, (c) glotalisasi, dan (d) palatalisasi, salah satu contohnya : Iki kelambi yang seharusnya Iki kelambai.

Pada KD ini dibutuhkan alat bantu berupa media atau bahan ajar yang sesuai. Menurut pendapat Suyatno (2004:60) mengenai teknik pembelajaran kosakata. Dia berpendapat bahwa salah satu teknik pembelajaran kosakata adalah dengan menggunakan teknik kata dari gambar. Oleh karena itu, perlu dikembangkan sebuah media yang mengkolaborasikan antara jajaran kata-kata dengan gambar.

Pada KD ini dibutuhkan alat bantu berupa media atau bahan ajar yang sesuai. Menurut pendapat Suyatno (2004:60) mengenai teknik pembelajaran kosakata. Dia berpendapat bahwa salah satu teknik pembelajaran kosakata adalah dengan menggunakan teknik kata dari gambar. Oleh karena itu, perlu dikembangkan sebuah media yang mengkolaborasikan antara jajaran kata-kata dengan gambar.

Berdasarkan identifikasi

permasalahan, peneliti menentukan konsentrasi penelitian pada permasalahan ketiga dan keempat yaitu hal yang berkaitan dengan kelangkaan buku referensi untuk mata pelajaran bahasa Using dan dibutuhkannya sebuah media pengajaran yang mengkolaborasikan antara kosakata dengan gambar. Penelitian ini nantinya akan terpusat mengenai pengembangan buku berbahasa Using bergambar.

Pengembangan buku berbahasa Using bergambar akan memberikan referensi baru terhadap khasanah kebudayaan Using dan untuk dapat digunakan sebagai penunjang pembelajaran bahasa Using. Pengembangan yang akan dilakukan oleh peneliti nantinya akan difokuskan pada 
FKIP UNIVERSITAS PGRI BANYUWANGI SEMINAR NASIONAL

Pendidikan Budaya dan Sejarah "Dibalik Revitalisasi Budaya"

ISBN: 978-602-72362-7-1

buku penunjang pembelajaran bahasa Using pada jenjang pendidikan Sekolah Dasar.

Berdasarka uraian di atas, masalah yang dikaji dalam penelitian ini adalah "Bagaimanakah Pengembangan Buku Berbahasa Using Bergambar sebagai Penunjang Pembelajaran Bahasa Using Sekolah Dasar".

Adapun tujuan yang ingin dicapai dalam penelitian ini adalah mengembangkan buku berbahasa Using bergambar sebagai penunjang pembelajaran bahasa Using Sekolah Dasar. Penelitian ini dilaksanakan bukan karena tanpa alasan, melainkan karena wujud dukungan kami sebagai peneliti di Perguruan Tinggi dalam mendukung 9 prioritas pemerintah daerah dan pilar visi misi pembangunan daerah Kabupaten Banyuwangi.

Salah satu prioritas dalam bidang pendidikan, antara lain: upaya peningkatan kualitas layanan pendidikan, inovasi Banyuwangi Cerdas, Banyuwangi Mengajar, Siswa Asuh Sebaya, inovasi layanan pendidikan dasar dan menengah, pemberantasan buta aksara, pendidikan kecakapan hidup, dan pendidikan inklusif. Peningkatan tata kelola sistem pendidikan dan pola kesejahteraan guru, serta peran serta masyarakat dalam mewujudkan pendidikan yang bermoral dan berakhlak mulia di Kabupaten Banyuwangi.

\section{METODE PENELITIAN}

Penelitian ini menggunakan pendekatan Research and Development $(R \& D)$ atau dapat pula disebut sebagai penelitian pengembangan. Sukmadinata (2008:164) menyatakan bahwa penelitian dan pengembangan merupakan suatu proses atau langkah-langkah untuk mengembangkan suatu produk baru atau menyempurnakan produk yang telah ada, yang dapat dipertanggungjawabkan.

Adapun langkah-langkah dalam melaksanakan penelitian pengembangan menurut pendapat Borg dan Gall (dalam Sukmadinata, 2008:169) ada sepuluh langkah, yaitu (1) penelitian dan pengumpulan data yang meliputi pengukuran kebutuhan, studi literatur, penelitian dalam skala kecil, (2) perencanaan dan pengembangan produk, (3) pengembangan produk awal, (4) uji coba produk awal, (5) penyempurnaan produk awal, (6) uji coba produk yang telah disempurnakan, (7) penyempurnaan produk yang telah disempurnakan, (8) pengujian produk yang telah disempurnakan, (9) uji lapangan produk yang telah disempurnakan, dan (10) diseminasi, implementasi, serta institusionalisasi.

Berdasarkan tahapan penelitian yang dikemukakan oleh Borg dan Gall, peneliti melakukan modifikasi tahapan menjadi enam tahap. Langkah ini diambil karena menyesuaikan kebutuhan penelitian dan tujuan penelitian. Adapun enam tahapan penelitian

yang akan dilakukan yaitu: (1) penyusunan konsep teori, (2) analisis kebutuhan, (3) pembuatan prototipe, (4) uji ahli, (5) revisi produk, dan (6) pengembangan prototipe. Tahap pertama yang dilakukan dalam rangka mengembangkan prototipe ini adalah penyusunan konsep teori yang berisikan kegiatan mencari sumber pustaka dan hasil penelitian yang relevan. Tahap berikutnya adalah tahap analisis kebutuhan. Pada tahap ini akan dilakukan aktivitas mencari data yang dibutuhkan 
dalam menyusun buku berbahasa Using bergambar.

Pada tahap ketiga merupakan tahap awal pembuatan prototipe buku berbahasa Using bergambar, meliputi kegiatan (a) mencari tema besar kosakata dan gambar yang akan dikembangkan untuk buku berbahasa Using bergambar untuk anak SD, (b) pengkajian formatm buku berbahasa Using bergambar untuk anak SD, dan (c) menyusun buku berbahasa Usinglbergambar untuk anak SD.

Tahap keempat merupakan tahap pengujian hasil pengembangan prototipe pertama kepada para ahli. Hasil dari pengembangan buku berbahasa Using bergambar akan diujikan kelayakannya kepada para ahli yang terdiri dari Guru, Dosen Ahli, dan Budayawan Using.

Tahap selanjutnya yaitu revisi prototipe buku berbahasa Using bergambar untuk anak SD yang meliputi: (a) mengidentifikasi dan mendata hasil penilaian dari guru, dosen ahli, dan budayawan Using, (b) mengolah data penelitian, dan (c) menemukan kelemahan pada produk. Tahap terakhir dalam membuat pengembangan adalah pengembangan buku berbahasa Using bergambar. Tahap-tahap pembuatannya dapat divisualisasikan dalam bagan berikut

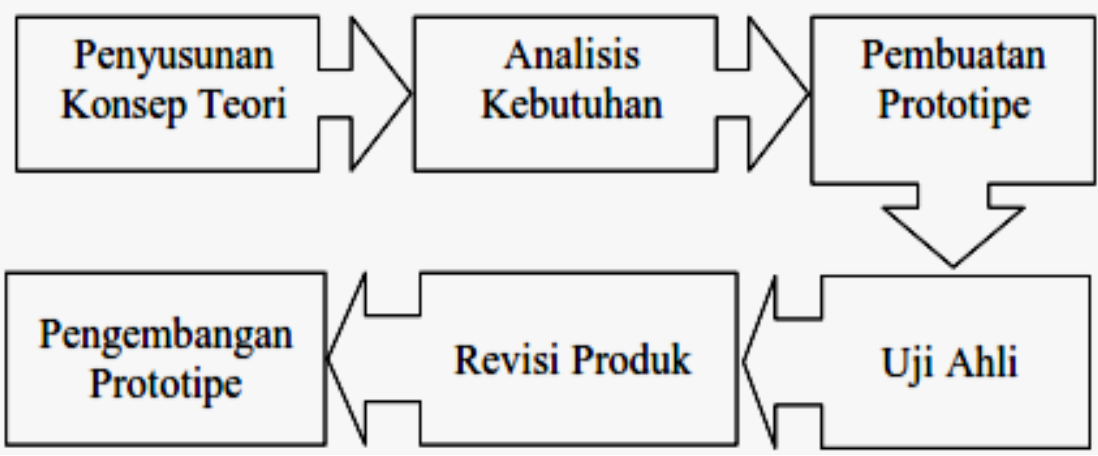

Gambar 3.1. Modifikasi Langkah-langkah penggunaan metode Research and Development $(R \& D)$

Subjek penelitian menurut Arikunto (2005:88) adalah benda, hal atau orang tempat data untuk variabel melekat, dan yang dipermasalahkan. Sesuai dengan fokus penelitian, yaitu pengembangan buku berbahasa Using bergambar untuk anak SD, subjek penelitian dalam penelitian ini sebagai berikut dibagi menjadi dua tahap. Subjek penelitian pada tahap analisis kebutuhan adalah guru, sedangkan subjek penelitian pada uji kelayakan produk adalah guru, dosen ahli, dan budayawan Using.

\section{PEMBAHASAN}

Pustaka yang mendasari penelitian ini yaitu hasil-hasil penelitian terdahulu yang memiliki keterkaitan dengan penelitian ini. Penelitian yang memiliki keterkaitan dengan hasil penelitian yang dilakukan oleh Lestari (2011), dan Fifana (2012), yang merupakan penelitian pengembangan. Penelitian yang dilakukan oleh Lestari (2011) mengembangkan sebuah buku bahan ajar 
FKIP UNIVERSITAS PGRI BANYUWANGI SEMINAR NASIONAL

Pendidikan Budaya dan Sejarah "Dibalik Revitalisasi Budaya"

ISBN: 978-602-72362-7-1

pembelajaran bahasa Indonesia yang disesuaikan dengan kurikulum pembelajaran bahasa Indonesia dengan objek siswa Sekolah Dasar pada pokok bahasan memahami cerita. Penelitian ini memiliki kesamaan yaitu pada jenis penelitian, objek penelitian, dan salah satu kajian penelitiannya.

Jenis penelitian yang dilakukan oleh Lestari adalah penelitian pengembangan yang menghasilkan sebuah produk buku bahan ajar yang berupa cerita rakyat. Produk tersebut selain berisi dialog juga memuat gambar sebagai visualisasi tokoh cerita. Jenis penelitian pengembangan ini mampu memberikan gambaran kepada peneliti untuk melakukan penelitian pengembangan walaupun produk yang dihasilkan berbeda. Lestari menghasilkan sebuah buku cerita bergambar sederhana. Penelitian yang dilakukan Lestari ini sama-sama memiliki objek siswa yaitu Sekolah Dasar. Adapun letak perbedaannya adalah jenjang yang diteliti. Lestari menjadikan keseluruhan jenjang siswa SD sebagai objek penelitian, sedangkan peneliti objek kajiannya pada siswa SD kelas IV, V, dan VI karena pengajaran bahasa Using SD di Banyuwangi pada kelas tinggi tersebut.

Sedikit berbeda dengan penelitian pengembangan yang dilakukan oleh Fifana (2002). Tidak ada kesamaan pada bagian objek atau kajian penelitian. Hanya saja, hipotesis penelitian yang ditemukan oleh Fifiana (2002) bisa dijadikan sebagai referensi untuk mengembangkan sebuah buku. Fifiana telah mengujikan buku produknya sehingga beberapa aspek hasil pengujiannya bisa dijadikan referensi untuk mengembangkan sebuah buku khususnya yang berkaitan dengan fisik buku. Peneliti bisa mengambil hasil penelitian, antara lain tentang hasil pengujian sampul, gambar, dan aspek kebahasaan. Hasil penelitian Fifiana tersebut membantu peneliti dalam membuat rancangan produk.

Dalam melakukan penelitian dan pengembangan produk, peneliti membutuhkan teoriteori akan dipaparkan, meliputi, (1) Buku, (2) Bahasa Using, (3) Gambar; dan (4) Karakteristik Psikolinguistik Siswa Sekolah Dasar.

\subsection{Buku}

Peneliti akan menjabarkan beberapa pada subbab referensi antara lain: a). jens buku, b). ciri-ciri buku nonteks, dan c). pembuatan buku pendidikan.

a) Jenis Buku

Berdasarkan klasifikasi yang dilakukan Pusat Perbukuan Departemen Pendidikan Nasional tentang buku-buku pendidikan (2004:4) diungkapkan terdapat empat jenis, yaitu buku teks pelajaran, buku pengayaan, buku referensi, dan buku panduan pendidik. Klasifikasi ini diperkuat lagi oleh Peraturan Menteri Pendidikan Nasional Nomor 2 tahun 2008 pasal 6 ayat (2) yang menyatakan bahwa "Selain buku teks pelajaran, pendidik dapat menggunakan buku panduan pendidik, buku pengayaan, dan buku referensi dalam proses pembelajaran". Berdasarkan ketentuan tersebut maka terdapat empat jenis buku yang digunakan dalam bidang pendidikan, yaitu (1) Buku Teks Pelajaran, (2) Buku Pengayaan, (3) Buku Referensi, dan (4) Buku Panduan Pendidik.

Untuk memudahkan dalam memberikan klasifikasi dan pengertian pada bukubuku pendidikan, dilakukan dua pengelompokan buku pendidikan yang ditentukan berdasarkan ruang lingkup kewenangan dalam pengendalian 
FKIP UNIVERSITAS PGRI BANYUWANGI SEMINAR NASIONAL

Pendidikan Budaya dan Sejarah "Dibalik Revitalisasi Budaya"

ISBN: 978-602-72362-7-1

kualitasnya, yaitu (1) Buku Teks Pelajaran, dan (2) Buku Nonteks Pelajaran, berdasarkan Permendikbud No. 8 Tahun 2016 tentang buku yang digunakan oleh satuan pendidikan, dinyatakan bahwa kewenangan untuk menilai atas kriteria kelayakan buku teks maaupun nonteks pelajaran adalah Kementerian atau Badan Standar Nasional Pendidikan (BSNP), sedangkan buku pengayaan, referensi, dan panduan pendidik bukan merupakan kewenangannya.

Berdasarkan pengelompokan di atas maka buku nonteks pelajaran berbeda dengan buku teks pelajaran. Jika dicermati berdasarkan makna leksikal, buku teks pelajaran merupakan buku yang dipakai untuk mempelajari atau mendalami suatu objek pengetahuan dan ilmu serta teknologi atau suatu bidang studi, sehingga karya kepanditaan (scholarly, literary) terkait subjek yang bersangkutan. Sementara itu, buku nonteks pelajaran merupakan buku-buku yang tidak digunakan secara langsung sebagai buku untuk mempelajari salah satu bidang studi pada lembaga pendidikan.

b) Ciri-Ciri Buku Nonteks

Berdasarkan pengelompokan di atas, dapat diklasifikasikan ciri-ciri buku nonteks pelajaran, yaitu sebagai berikut.

(1) Buku-buku yang dapat digunakan di sekolah atau lembaga pendidikan, namun bukan merupakan buku pegangan pokok bagi peserta didik dalam mengikuti kegiatan pembelajaran.

(2) Buku-buku yang tidak menyajikan materi pembelajaran yang dilengkapi dengan instrumen evaluasi dalam bentuk tes atau ulangan, latihan kerja (LKS) atau bentuk lainnya yang menuntut pembaca melakukan perintah-perintah yang diharapkan penulis.

(3) Buku-buku nonteks pelajaran tidak diterbitkan secara berseri berdasarkan kelas atau jenjang pendidikan.

(4) Buku-buku nonteks pelajaran berisi materi yang tidak terikat secara langsung dengan sebagian atau salah satu Standar Kompetensi atau Kompetensi Inti yang tertuang dalam Standar Isi, namun memiliki keterhubungan dalam mendukung pencapaian tujuan pendidikan nasional.

(5) Materi atau isi dari buku nonteks pelajaran dapat dimanfaatkan oleh pembaca dari semua jenjang pendidikan dan tingkatan kelas atau lintas pembaca, sehingga materi buku nonteks pelajaran dapat dimanfaatkan pula oleh pembaca secara umum.

(6) Penyajian buku nonteks pelajaran bersifat longgar, kreatif, dan inovatif sehingga tidak terikat pada ketentuanketentuan proses dan sistematika belajar yang ditetapkan berdasarkan ilmu pendidikan dan pengajaran.

c) Pembuatan Buku Pendidikan

Aqib (2013:52) mengemukakan prinsip pembuatan buku sebagai berikut.

(1) Visible yaitu memuat isi yang mudah dilihat.

(2) Interesting yaitu menarik.

(3) Simple yaitu sederhana.

(4) Useful yaitu bermanfaat untuk sumber ilmu pendidikan.

(5) Accourate yaitu benar dan tepat sasaran.

(6) Legitimate yaitu sah dan masuk akal.

(7) Structured yaitu tersusun secara baik dan runtut.

Prastowo (2012) mengemukakan teknik penyusunan buku pendidikan cetak 
FKIP UNIVERSITAS PGRI BANYUWANGI SEMINAR NASIONAL

Pendidikan Budaya dan Sejarah "Dibalik Revitalisasi Budaya"

ISBN: 978-602-72362-7-1

yaitu dengan langkah-langkah sebagai berikut.

(1) Judul dan meteri yang disajikan berintikan pada pencapaian kompetensi dasar atau materi peserta didik.

(2) Memuat bahasa yang mudah dipahami sesuai dengan perkembangan kebahasaan sasaran penggunanya.

(3) Mampu menguji pemahaman siswa terhadap suatu hal.

(4) Adanya stimulan yaitu berkaitan dengan nyaman dan tidaknya sebuah tampilan sehingga mendorong pembaca untuk mendalaminya.

(5) Kemudahan dibaca berkaitan dengan keramahan bahan cetak jika dihadapkan dengan indera penglihat (mata), misalnya tebal tipis, ukuran huruf, warna, dan jenis kertas.

\subsection{Bahasa Using}

a) Definisi Bahasa Using

Menurut peneliti asal Belanda, J.G.W Lekkerkerker, dalam studinya mengenai sejarah ujung timur Pulau Jawa yang terbit di Belanda pada tahun 1923, istilah"Using” digunakan untuk menyebut suku di Banyuwangi dan penutur bahasanya. "Mereka yang disebut ,orang Usinge (de z.g.n. Oesingers) (dari „usingee, „sing ${ }^{\text {ee }}$, kata pribumi sebenarnya bahasa Bali- untuk ,tidak ${ }^{\text {ee }}$ ”. Lekkerkerker juga mencatat bahwa kepribadian, bahasa, dan adat orang Using sangat berbeda dari orang Jawa lainnya.

Pada zaman itu, kelompok ini dianggap dan kemungkinan besar menganggap dirinya orang Jawa. Sampai kira-kira pada tahun 1970 mereka masih lazim digolongkan sebagai orang Jawa, dan sekarang pun kategorisasi ini masih terdengar, terutama di lingkungan pedesaan. Tetapi, sering kali ada catatan bahwa kebudayaan mereka, termasuk bahasa, berbeda juga. Mereka adalah wong Jawa Using, yaitu orang Jawa yang menggunakan kata Using untuk mengatakan ,tidak ${ }^{\text {ee }}$, sedangkan orang Jawa lainnya berkata nggak atau ora dengan arti sama.

b) Sistem Pengucapan atau Fonologi

$\begin{array}{ccc}\text { Bahasa } & \text { Using } & \begin{array}{c}\text { mempunyai } \\ \text { kelafalannya, }\end{array}\end{array}$ antara lain:

(1) Adanya diftong [ai] untuk vokal [i] : semua leksikon berakhiran "i" pada bahasa Using khususnya Banyuwangi selalu terlafal "ai". Seperti misalnya "geni" terbaca "genai", "bengi" terbaca "bengai", "gedigi" (begini) terbaca "gedigai".

(2) Adanya diftong [au] untuk vokal $[u]$ : leksikon berakhiran " $u$ " hampir selalu terbaca "au". Seperti "gedigu" (begitu) terbaca "gedigau", "asu" terbaca "asau","awu" terbaca "awau".

(3) Lafal konsonan [k] untuk konsonan [q]. Di bahasa Jawa, terutama pada leksikon berakhiran huruf " $k$ " selalu dilafalkan dengan glottal "q". Sedangkan di Bahasa Using, justru tetap terbaca " $k$ " yang artinya konsonan hambat velar. Antara lain "apik" terbaca "apiK", "manuk", terbaca "manuK" dan seterusnya.

(4) Konsonan glotal [q] yang di bahasa Jawa justru tidak ada seperti kata [piro ${ }^{e c}$ ], [kiwo $\left.{ }^{e c}\right]$, dan seterusnya.

(5) Palatalisasi [y] dalam bahasa Using, kerap muncul pada leksikon yang 
FKIP UNIVERSITAS PGRI BANYUWANGI SEMINAR NASIONAL

Pendidikan Budaya dan Sejarah "Dibalik Revitalisasi Budaya"

ISBN: 978-602-72362-7-1

mengandung [ba], [ga], [da], [wa]. Seperti "bapak" dilafalkan "byapak", "uwak" dilafalkan "uwyak", "embah" dilafalkan "embyah", "Banyuwangi" dilafalkan "Byanyuwangi", "dhawuk" dibaca "dyawuk".

c) Gaya Penggunaan Bahasa

\section{Di Kabupaten Banyuwangi} khususnya dikalangan masyarakat Using, dikenal dua gaya bahasa yang satu sama lain ternyata tidak saling berhubungan. Yakni Cara Osing dan Cara Besiki. Cara Osing adalah gaya bahasa yang dipakai dalam kehidupan sehari-hari, dan tidak mengenal bentuk Ngoko-Krama seperti layaknya Bahasa Jawa umumnya. Yang menjadi pembedanya adalah pronomina yang disesuaikan dengan kedudukan lawan bicara, misalnya :

(1) Siro wis madhyang? = kamu sudah makan?

(2) Riko wis madhyang? = anda sudah makan?

o Hiro/Iro = digunakan/lawan bicara untuk yang lebih muda(umur)

o Siro = digunakan/lawan bicara untuk yang selevel(umur)

o Riko = digunakan/lawan bicara untuk yang di atas kita (umur)

o Ndiko = digunakan/lawan bicara untuk orang tua (bapak/ibu)

Sedangkan Cara Besiki adalah bentuk "Jawa Halus" yang dianggap sebagai bentuk wicara ideal. akan tetapi penggunaannya tidak seperti halnya masyarakat Jawa, Cara Besiki ini hanya dipergunakan untuk kondisi-kondisi khusus yang bersifat keagamaan dan ritual perkawinan atau kematian. Sebagaimana ungkapan ini "Sutupa ingkang wangsul teng alam kelanggengan, ageng alit mangga sami- sami diterami, inggih" (Sutapa yang pulang ke alam baka, besar-kecil marilah sama-sama diterima). Ungkapan bahasa ini sangat halus bagi masyarakat Using daripada menggunakan bahasa ungkapan "Sutupa hang wis moleh neng akhirat, cilik gedeni salae ayuk podopodo diterimo yo", ungkapan ini memiliki arti dan esensi makna yang sama. Akan tetapi masyarakat Using lebih menggunakan ungkapan bahasa yang pertama, karena dinilai lebih sopan dan menghormati pada orang lain, meskipun itu sudah meninggal dunia.

\subsection{Gambar}

Peneliti akan menjabarkan subbab gambar dengan menjabarkan mengenai (1)pengertian gambar; (2) manfaat gambar untuk pembelajaran bahasa; (3) pemilihan fotoatau gambar dalam pembelajaran; dan (4) pengembangan media gambar

a) Pengertian Gambar

Berdasarkan pengelompokan jenis bahan ajar menurut bentuknya, gambar merupakan bahan ajar cetak. Menurut cara kerjanya, gambar merupakan bahan ajar yang tidak diproyeksikan yaitu bahan ajar yang tidak memerlukan alat untuk memproyeksikan isi di dalamnya sehingga peserta didik secara langsung menggunakan (membaca, melihat, mengamati) bahan ajar tersebut.

Menurut Iswidayati (2010:59) gambar merupakan media visual duamatra yang tidak memerlukan alat penampil untuk penyajiannya. Dikaitkan dengan gambar sebagai media pembelajaran, media gambar adalah berbagai bentuk bagan, diagram grafik, penampang, tabel, dan visual image 
FKIP UNIVERSITAS PGRI BANYUWANGI SEMINAR NASIONAL

Pendidikan Budaya dan Sejarah "Dibalik Revitalisasi Budaya"

ISBN: 978-602-72362-7-1

lainnya yang dapat dimanfaatkan untuk pembelajaran siswa.

Peneliti menyimpulkan pengertian gambar seperti halnya yang disampaikan oleh Iswati yaitu media visual yang tidak memerlukan alat penampil untuk penyajiannya sehingga dapat digunakan untuk media pembelajaran. Pengertian ini lebih tepat digunakan untuk mendefinisikan gambar pada kamus bergambar yang akan dibuat oleh peneliti. b) Manfaat Gambar untuk Pembelajaran Bahasa

Sebelum berbicara lebih lanjut mengenai kegunaan gambar dalam pembelajaran bahasa, alangkah baiknya jika diuraikan terlebih dahulu pentingnya media secara umum dalam proses belajar mengajar. Adapun manfaat media menurut Sudjana dan Rivai (2007:35) antara lain adalah:

1) memudahkan pengertian ketika anak-anak sedang mendengarkan;

2) dapat melafalkan dengan baik arti dari kosa kata;

3) dapat membaca dengan benar;

4) tersedianya suatu topi kata;

5) memudahkan jalan komunikasi antara guru dan siswa.

c) Pemilihan Foto atau Gambar dalam Pembelajaran

Dalam rangka melakukan proses pembelajaran, pemilihan jenis media harus diperhatikan secara seksama. Begitu juga dengan memilih foto/gambar yang akan digunakan untuk media belajar. Menurut Prastowo (2012:382383) ada beberapa hal yang harus diperhatikan dalam memilih media foto/ gambar, sebagai berikut.

1) Substansi materi yang disajikan dalam bentuk foto/ gambar sebaiknya memiliki relevansi dengan kompetensi yang harus dikuasai oleh peserta didik.

2) Gambar yang disajikan dapat dipertanggungjawabkan kebenarannya.

3) Gambar ditampilkan dalam skala yang sesuai sehingga logis dan nyaman dilihat.

4) Gambar menampilkan judul dan keterangan

Sesuai dengan pendapat diatas, pemilihan foto atau gambar dalam pembuatan kamus bergambar adalah sebagai berikut.

1) Gambar yang disajikan tidak memiliki kesan dan menampilkan pornogra fulgar.

2) Gambar ditampilkan dengan ukuran yang sesuai dengan ukuran buku.

3) Gambar menampilkan judul dan keterangan yang terperinci.

4) Pemilihan gambar menyesuaikan kebutuhan pembelajaran peserta didik.

d) Pengembangan Media Gambar

Prinsip-prinsip pengembangan media menurut Arsyad (2007:105-106) adalah:

1) mengidentifikasi batasan tema bahasan;

2). mengidentifikasi tujuan pengembangan;

3) merumuskan tujuan pengembangan;

4) mengevaluasi karakteristik objek sasaran media;

5) menyiapkan online materi;

6) mempertimbangkan media yang paling tepat untuk sebuah materi;

7) menyiapkan keterangan gambar;

8) mencari ahli dalam masingmasing bidang untuk membantu pembuatan.

4. Karakteristik Psikolinguistik Siswa Sekolah Dasar 
FKIP UNIVERSITAS PGRI BANYUWANGI SEMINAR NASIONAL

Pendidikan Budaya dan Sejarah "Dibalik Revitalisasi Budaya"

ISBN: 978-602-72362-7-1

Masa anak Sekolah Dasar (SD) berlangsung antara usia 6/7 tahun sampai 12/13 tahun. Kelas pada jenjang Sekolah Dasar terdiri atas kelas I, II, III, IV, V, dan VI, anak usia SD merupakan anak yang berada pada dua tahapan perkembangan kognitif yaitu stadium operasional konkret (7-11 tahun) dan stadium operasional formal (mulai 11 tahun). Menurut Monks dan Knoers (dalam Haditomo 2002:222-223), ciri-ciri anak pada stadium operasional konkret antara lain, cara berpikir anak kurang egosentris dan anak mampu untuk melakukan aktivitas logis tertentu (operasi) tetapi hanya dalam situasi yang konkret. Sehingga anak pada stadium ini sudah mampu berpikir bukan hanya untuk dirinya sendiri tetapi sudah mampu menyelesaikan masalahnya sendiri dengan baik jika dihadapkan pada situasi nyata dan contoh-contoh yang nyata.

Berdasarkan pendapat Hasan (2006:216) perkembangan bahasa sebagai interaksi antara hasil belajar dan kemampuan alamiah individu. Perkembangan psikolinguistik anak yang dipaparkan oleh Hasan (2006:216) adalah sebagai berikut.

a) Pada usia 0-1 tahun, seseorang sudah mulai melakukan isyarat praverbal, memperhatikan sesuatu disertai dengan objek, menangkap bahasa pertama (B-1), memahami kata tunggal, dan mulai menemukan arti kata yang mereka pahami secara mandiri.

b) Pada usia 1-2 tahun, seseorang mulai menampung perbendaharaan kata, adanya gejala pengucapan kosakata, dan memiliki kemampuan dalam berkomunikasi dengan ditandai dengan mengucapkan suatu kata secara bergantian. c) Pada usia 3-5 tahun, seseorang sudah mulai mengalami peningkatan pengucapan kosakata, sudah mulai menggunakan perbendaharaan kata yang tepat untuk berkomunikasi, dan mulai memahami setiap kata yang diucapkan sehingga adanya kesamaan maksud dari yang diucapkan dengan yang diinginkan.

d) Pada usia 6-11 tahun, seseorang sudah mulai mengutarakan kalimat seperti orang dewasa, mulai memunculkan ekspresi yang sesuai dengan maksud kata, memiliki kemampuan untuk mendeteksi dan memperbaiki pesan yang diterima, dan memiliki kemampuan melakukan perbaikan kosakata yang salah.

Dari paparan di atas, dapat disimpulkan bahwa usia SD adalah waktu yang baik untuk memberikan kosakata yang benar sesuai dengan kondisi lingkungan sosialnya untuk menghasilkan rekaman bahasa yang sesuai untuk komunikasi. Hal itu karena mereka pada usia SD adalah seseorang individu yang mampu mengolah dan merekam pesan yang baik sehingga akan menjadi memori yang akan menjadi bekal dalam berinteraksi.

\section{DAFTAR PUSTAKA}
Ali, Hasan. 2001. Kamus Bahasa Daerah Using-Indonesia. Banyuwangi: Dewan Kesenian Blambangan Banyuwangi.

Aqib, Zainal. 2013. Model-Model Media, dan Strategi Pembelajaran Kontekstual (Inovatif). Bandung : CV YRAMA WIDYA.

Arikunto, Suharsimi. 2005. Manajemen Penelitian. Jakarta: PT Rineka Cipta. 
FKIP UNIVERSITAS PGRI BANYUWANGI SEMINAR NASIONAL

Pendidikan Budaya dan Sejarah "Dibalik Revitalisasi Budaya"

ISBN: 978-602-72362-7-1

Arsyad, Azhar. 2009. Media Pembelajaran. Jakarta: Rajawali Press.

Desmita. 2010. Psikologi Perkembangan Peserta Didik. Bandung: PT Remaja Rosdakarya.

Fifana, Riyadloh. 2012. Pengembangan Panduan Membuat Majalah Sekolah untuk Siswa SMP. Skripsi. Jurusan Bahasa dan Sastra Indonesia, Fakultas Bahasa dan Seni, Universitas Negeri Semarang.

Haditomo, S. 2002. Psikologi Perkembangan Pengantar dalam Berbagai Bagiannya. Yogyakarta: Kanisius.

Hasan, Aliah B. Purwakania. 2006. Psikologi Perkembangan Islam Menyingkap Rentang Kehidupan Manusia dari Prakelahiran hingga Pascakematian. Jakarta: Rajawali Press.

Lestari, Tri. 2011. Pengembangan Bahan Ajar Cerita Berbasis Konservasi Budaya Bagi Siswa SD Kelas Tinggi. Skripsi. Jurusan Bahasa dan Sastra Indonesia, Fakultas Bahasa dan Seni, Universitas Negeri Semarang.

Menteri Pendidikan dan Kebudayaan Republik Indonesia. 2016. Permendikbud No. 8 Tahun 2016 tentang Buku yang digunakan oleh Satuan Pendidikan. Jakarta: Dirjen Peraturan Perundang-Undangan Kemenkumham RI.

Prastowo, Andi. 2012. Panduan Kreatif Membuat Bahan Ajar Inovatif. Yogyakarta: Diva Press .

Pusat Perbukuan. 2004. Pedoman Klasifikasi Buku Pendidikan. Jakarta: Pusat Perbukuan Depdiknas.
Sudjana, N. dan A. Rivai. 2007. Media Pengajaran: Penggunaan dan Pembuatannya. Bandung: Sinar Baru Algensindo.

Suyatno. 2004. Teknik Pembelajaran Bahasa dan Sastra. Surabaya: SIC.

Tim. Bappeda. 2017. Pedoman Penyusunan Proposal Penelitian. Panduan. Bappeda. Pemerintah Kabupaten Banyuwangi https://id.m.wikipedia.org/wiki/Bahasa_O sing 